\title{
Cold War Television Diplomacy
}

\section{The German Democratic Republic on Finnish television}

\author{
Laura Saarenmaa ${ }^{\mathrm{I}}$ \& Marie Cronqvist ${ }^{\mathrm{II}}$ \\ I Department of Media Studies, University of Turku, Finland \\ II Department of Communication and Media, Lund University, Sweden
}

\begin{abstract}
This article opens a new perspective on Finland's Cold War history by highlighting the role of the Finnish Broadcasting Company (YLE) in providing information about the German Democratic Republic as a particular polity, economy, and key player in the European Cold War landscape. The analysis is based on search results from the YLE digital database (Metro) from 1970-1989, and it is supported by documents from the German Broadcasting Archive [Deutsches Rundfunkarchiv] and the YLE company archive. The archive documents and metadata testify about a long-term interest in East Germany in Finnish television, as well as long-term contacts and collaboration between East German and Finnish television companies, in the executive as well as at grass roots levels.
\end{abstract}

Keywords: Cold War, the Finnish Broadcasting Company (YLE), the German Democratic Republic (GDR), public diplomacy, television diplomacy

\section{Introduction}

Following the formal diplomatic recognition of the German Democratic Republic (GDR) by the Nordic countries in 1972, an intensive collaboration over the Baltic Sea was initiated in a number of societal fields (Almgren, 2009; Hentilä, 2006; Linderoth, 2002; Åkerlund, 2011), one of which was broadcasting, particularly public service television. As an accommodating yet non-aligned neighbour of the Soviet Union, Finland was an important target for the diplomatic attention and influence of the GDR; however, Finns were hardly passive objects of diplomatic pressure. Rather, there were strong sympathies for the East Germans among the Finnish public, political elite, and media (Hentilä, 2004, 2006; Rusi, 2007, 2012).

While earlier research on the relations between Finland and the GDR has concentrated on political parties and organisations, top politicians, and the field of state diplomacy (Hentilä, 2004, 2006; Rusi, 2007, 2012), the perspectives of the public and the media have remained unexplored. Thus, this article opens a new perspective on Finland's Cold War history by examining the role of the state-run, license fee-funded public service

Saarenmaa, L., \& Cronqvist, M. (2020). Cold war television diplomacy: The German Democratic Republic on Finnish television. Nordicom Review, 41(1), 19-31. https://doi.org/10.2478/ nor-2020-0002 
television company, the Finnish Broadcasting Company (YLE), in maintaining and deepening diplomatic relations with East Germany, from the recognition of East Germany in 1972 to the fall of the Berlin Wall in 1989. ${ }^{1}$

\section{Method and data}

The analysis is based on search results from YLE's digital media management system, Metro, using the search terms "DDR" and "Saksan Demokraattinen Tasavalta" ["GDR" and "German Democratic Republic"]; the examined period stretches from 1970 to 1989. Metro was launched in 2009 to archive the digitised YLE collections from 1957 onwards, and it is available for research via the YLE information service. The search results from the database include the metadata of the programming, not actual programmes or clips. ${ }^{2}$

The metadata itself come from reports, news inserts, and programmes with any reference to the GDR on the two national Finnish television channels (including Swedish news and current affairs programming for the Finnish Swedish-language-speaking minority). All in all, the analysed material consists of 1,469 pages (270 pages from 1970-1979; 348 pages from 1980-1985; and 851 pages from 1986-1989) of textual metadata, including information on programme titles, editors, dates and times of broadcast, duration of programming, and occasionally short descriptions of the visual and verbal content of the material. Sports results form a substantial part of the material, but are not within our frame of attention here.

When excluding sports, the majority of the search results consists of news and current affairs programmes, including reports and inserts by YLE foreign correspondents. In addition, the search results include information on feature films, series, and television theatre productions imported from the GDR or produced in collaboration with YLE drama production and Fernsehen der DDR [East German television] (DDR-FS). Documentaries, features, and history programmes that mention the GDR or use DDR-FS archive materials or news footage are also included. The categorisation was executed through rough manual content analysis, excluding sports and organising the remaining programme listings into three thematic categories: 1) state-level interaction, 2) history politics, and 3) representations of everyday life.

By analysing textual metadata made available for research, the article contributes to the debate on the use of digital archives in media historical research. As pointed out by Strandgaard Jensen (2016), the problem of digital television archives lies in their incoherencies, inconsistencies, and the limited availability of metadata. The metadata of the Metro database have been written and filed by journalists, editors, and archiving personnel with altering terms, keywords, and criteria through the decades, and hence the search results cannot be treated as reliable data of the programming as a whole - there might be misses, mistakes, and gaps. However, digital databases such as Metro make it possible to get an idea about the volume of programming over time. Moreover, a benefit of relying on database search results is that they indicate the variety of different genres and programme types - news, current issues reports, documentaries, feature films, and culture programmes. While textual metadata lack the visual information of actual images, they provide information on news criteria, programme planning, scheduling, and the continuities of broadcasting at the institutional and corporate levels. 
The analysis of the database search results is supported by archive documents at the German Broadcasting Archive [Deutches Rundfunkarkiv] (DRA) and the YLE company archive collections with the collaboration of the member countries of Organisation Internationale de Radiodiffusion et de Télévision [International Radio and Television Organisation] (OIRT). The DRA collection includes contracts, annual work plans, and correspondence between YLE representatives and DDR-FS representatives, minutes, travel reports, cuts, summaries and translations, and statistical information on television in Finland. DRA had a more diligent archiving culture than they had at YLE, but the flow of reports, programmes, and films from East Germany broadcast on Finnish television nevertheless illustrates evidence of long-term contacts and collaboration between the companies.

\section{Histo-political background}

The post-war relations between Finland and East Germany were officially locked in an irreconcilable contradiction. On the one hand, the 1948 Finno-Soviet Treaty of Friendship, Cooperation, and Mutual Assistance singled out West Germany as a military threat to the two signatories. On the other hand, the West German Hallstein Doctrine of 1955 considered the recognition of the GDR by anyone but the Soviet Union a hostile act towards the Federal Republic of Germany (FRG). Unable to establish friendly ties with one state without upsetting the other, Finland thus remained the only country in the world to maintain a strictly neutral position towards both German states. Only after Willy Brandt's Ostpolitik [new eastern policy] had resulted in the Grundlagenvertrag [Basic Treaty] between East and West Germany in December 1972 could the Gordian knot be cut and diplomatic relations between Finland and both German states established (Hentilä, 2006).

The lack of official recognition, however, did not mean an absence of culture and trade relations, and both German states opened commercial offices in Helsinki in the early 1950s. Throughout the 1960s and early 1970s, the GDR launched several initiatives designed to convince Finland to recognise the country diplomatically. These initiatives addressed Finnish civic and cultural organisations, journalists, university students, researchers, and other unofficial channels in the hope that they could in turn promote official Finnish recognition of East Germany (Hentilä, 2004, 2006). The GDR used the same strategy in Finland's equally neutral neighbour Sweden (Åkerlund 2011; Almgren 2009; Linderoth, 2002).

Finland's exceptional position between East and West was also apparent in the field of broadcasting. YLE was a full member of both the Western European Broadcasting Union and its distribution network Eurovision, and the Eastern International Broadcasting Organisation (renamed the International Radio and Television Organisation, or OIRT, in 1960) and its distribution network Intervision. Although the Soviet propagandist nature of OIRT was understood in the YLE leadership (Salokangas, 1996), the company collaborated actively with the leading OIRT members - the Soviet Union, the GDR, Poland, Hungary, Bulgaria, Czechoslovakia, and Romania - in conforming to the official Finnish foreign policy of balancing and bridge-building between East and West (Salokangas, 1996). Hence, although the links with the West were probably always more prominent, contacts with socialist television cultures coloured the Finnish television environment during the Cold War (Pajala, 2014). ${ }^{3}$ 
In the 1970s spirit of foreign political balancing, YLE appointed Knud Möller, a permanent foreign correspondent in East Berlin (from 1974-1977), to balance their West German reporting (Salokangas, 1996). However, due to the limited possibilities of journalists to work freely in the GDR, the reports of the East Berlin correspondent focused mostly on the mundane aspects of everyday life; Finnish news media - including YLE - barely reported on GDR's violations of human rights, environmental destruction, structural economic problems, shortage of consumer goods, or the privileging of the nomenclature before the 1990s. Finnish historian Seppo Hentilä sees this cautious style of GDR-reporting as an ingredient of "Finlandisation": the Finnish Cold War mindset that reached its self-censoring nadir in the 1970s. Finlandised news reporting adopted the foreign political phraseology and discourse of Soviet-friendliness, and avoided issues and subjects unpleasant to the Soviet Union and its socialist allies (Lounasmeri, 2013; Salminen, 1999; Salokangas, 2015; Seppinen, 2011; Uskali, 2003; Vihavainen, 1991).

To what extent the Finlandisation of YLE was actively imposed by the Soviets, and how much the self-censorship was pre-emptively embraced, is a subject of ongoing debate among Finnish historians. For some scholars, the situation resembled a "full-scale information war" (Vihavainen, 2011: 138); for others, the Finnish cautiousness was a necessary concession and thus a clever act of tightrope-walking between the blocs (on the different interpretations, see Lounasmeri, 2013; Uskali, 2003; Salminen, 1999). The debate has centred on the journalistic integrity and quality of the Soviet reporting and the postulated KGB connections to the management of YLE (Salokangas, 2015; Vihavainen, 2011).

However, the East German Socialist Unity Party (SED) and the Ministry for State Security also paid close attention to what was happening in Finland and monitored the Finnish media (Vihavainen, 2011). The GDR news agency Allgemeiner Deutcher Nachrichtendienst, known for its double role in the service of intelligence, had a permanent correspondent in Helsinki from 1959 onwards (Hentilä, 2004; Minholz \& Stirnberg, 2012), and the Helsinki DDR Kulturzentrum [GDR Cultural Centre] sought to influence the Finnish public and collaborated actively with YLE's culture department. From the perspective of YLE culture journalists, collaboration with the GDR Cultural Centre and GDR television representatives was in line with the YLE programme policy (updated in 1972) that emphasised education, cultural sophistication, and geopolitical diversity and supported the official foreign political aims of political balancing. Programmes about the OIRT countries thus balanced the share of American entertainment in Finnish television and supported the YLE programme political ideals of multifaceted-ness (Pajala, 2018a, 2018b). Moreover, East Germany, an active member of OIRT, was geographically and culturally close, and many YLE executives and journalists spoke German.

\section{Diplomacy through television}

As Finland was seen as a key country [Schwerpunktsland] in the GDR's Western diplomacy, the foreign political aims explain the East German interests in visibility in Finnish television. Thomas Beutelschmidt and Richard Oehmig (2014) have noted that existing research on the GDR has largely neglected East German media integration with the West: the continuous exchange of news, the joint broadcasting of major sports and political events, the intense trade in films, and the encounters at festivals and trade fairs. 
More generally, the East-West cultural interaction has been addressed in the body of work on the Cold War and cultural diplomacy (Imre et al., 2013; Autio-Sarasmo \& Miklóssy, 2011; Mikkonen et al., 2019; Mikkonen \& Koivunen, 2015; Mikkonen \& Suutari, 2016; Richmond, 2003; Vowinckel et al., 2012). Here, we use the term "television diplomacy" to draw particular attention to the role of public service television in providing news, views, and information about foreign (socialist) countries, and in articulating and interpreting state-level diplomatic relations and foreign policy goals. In research on international relations, the role of news media has been discussed in terms of "public diplomacy", "soft power", and "new public diplomacy" (Cohen, 1986; Gilboa, 2001; Malek, 1997; Melissen, 2005; Pamment, 2016; Richmond, 2008). While public diplomacy refers broadly to communication for the purpose of promoting national interest and advancing foreign policy goals, television diplomacy here refers specifically to broadcast television as a medium, arena, and instrument for public diplomacy. Yoel Cohen's pioneering book on the relationship of news media and modern diplomacy explains the particular role of media diplomacy within public diplomacy: "Media diplomacy includes all those aspects of public diplomacy where the media are involved [...], including the sending of signals by governments through the media, and the use of media as a source of information" (1986: 7).

In his critical revision of Cohen's definition, Eytan Gilboa (2001) states that separating from public diplomacy - and conducted in the context of confrontation - media diplomacy is pursued in the context of conflict resolution and designed to create a friendly climate within a foreign society towards fundamental political and social issues. This study deploys this conceptual framework in a European Cold War setting and argues that Finnish public service television was applied as a medium, arena, and instrument for creating a friendly climate despite the fundamental differences between Finland and the GDR.

Recent European television history has acknowledged the transnational dimensions of European Cold War television culture (Badenoch et al., 2013; Henrich-Franke \& Immel, 2013; Lundgren, 2015). Moreover, television scholars have begun to question the East-West binary that has hindered scholars from identifying similarities between socialist and nonsocialist television cultures (Mihelj, 2013; Mustata, 2012) and the efforts to overcome the East-West divide through transnational programme production (Lundgren \& Evans, 2017). In a similar vein, Finnish television historian Mari Pajala (2018b) has called for European television history that acknowledges a multiplicity of relations between socialist and nonsocialist Europe.

Here, we will focus on the particular relation between the GDR and the Finnish Broadcast company YLE, paying particular attention to the GDR as a subject of news and current issues programming. Firstly, this is to show more evidence of the circulation of socialist worldviews outside the socialist bloc, and secondly, to argue for the centrality of television in the European Cold War public mindset. In our analysis of the search results from the YLE Metro database, we identified three main categories of GDR-related programming: 1) state-level interaction, 2) history politics, and 3) representations of everyday life. In the following, we will introduce representative samples of these categories and discuss them as features of Finnish-East German television diplomacy. 


\section{State-level interaction - warm welcomes at the airport}

The first category of the Metro database search results includes news on state-level interaction between the GDR and Finland, mostly consisting of official and unofficial visits between high-ranking representatives of the countries. In addition to visits between Finland and the GDR, the visits between the Soviet Union and the GDR were reported regularly, as well as visits and negotiations between the GDR and the FRG. Hence, interest in the German states was not limited to situations where Finland was directly involved, as the relations between the Soviet Union, West Germany, and East Germany were considered newsworthy as well. The Metro database search results show that the meetings and negotiations designed to normalise, develop, and improve the relations between the two German states took the form of an ongoing narrative in the Finnish national news flow from the early 1970s up to the end of the Cold War.

Dayan and Katz (1992) underline the importance of state visits in practising the "politics of détente" and creating a reciprocal sense of trust. The repetitious footage of state heads meeting at airports, and their warm, friendly handshakes, could be seen as evidence of trust and goodwill between the parties - gestures that reinforced the sense of security among news-watching citizens. Furthermore, the repetitious images of welcome and farewell ceremonies at airports included detailed information on Cold War geography, international relations, diplomatic protocol, and reciprocal attitudes and hierarchies between the parties. In this regard, YLE reporting was careful to mention at which airport the landing, and welcome and farewell ceremonies, took place. For example, when Chancellor of the FRG Helmut Schmidt visited the GDR in December 1981, it was reported that SED leader Erich Honecker welcomed Schmidt at Schönefeld Airport. When Honecker in his turn visited the FRG in September 1987, Finnish viewers were informed that he was welcomed by the Minister of Special Affairs Wolfgang Schäuble at Cologne Bonn Airport and then escorted to meet Federal Chancellor Helmut Kohl, in order to attend the official welcoming ceremonies. Honecker's farewell ceremonies at Munich Airport, again, were reported as being hosted by the Bavarian Prime Minister Franz Josef Strauss after visiting Honecker's hometown of Wiebelskirchen, Bavaria.

On-location television footage at the airport worked as documentation of the actual moment of encountering: the physical presence of the parties, their bodily gestures, and expressions of personal recognition and affection. Television diplomacy works within these kinds of images - in recording and mediating the state-level meetings as loaded with foreign political symbolic and diplomatic protocol and manifold political and personal preferences. In fact, the very presence of the television cameras is itself a diplomatic gesture in recognising the importance of the encounter and the welcoming ceremonies as media events (Couldry et al., 2009).

In part, the flow of information about state visits can be explained by the then-current news criteria. At that time, it was difficult to obtain updated information beyond the official foreign political phraseology. The negotiations took place behind closed doors and the informing and briefing of the news media was scarce. Moreover, the news was shot in film, and on-location shooting was a demanding task to execute. Hence, from a practical point of view, the organised welcoming ceremonies were "good news": all the parties would be in place at the same time, and they were expected to act according to the written script. Moreover, the YLE newsroom had good contacts within the presidential office, and they shared an understanding of the political significance of the 
state visits (Pernaa, 2009).

During the negotiation process leading up to the diplomatic recognition of the GDR, non-state-level visitors from the GDR were also shown arriving at Helsinki Airport. For instance, YLE television news reported in November 1971 that the SED representative Herman Axen visited Helsinki, and the head of the Finnish Communist Party Aarne Saarinen welcomed him at the airport (YLE News, 7 November 1971). Given Finland's official non-relationship with the GDR, the decision to cover Axen's visit was evidently taken by the editors, rather than simply being based on default state diplomacy. Through such decisions, YLE bestowed the GDR recognition negotiations with symbolic importance.

After the recognition and establishment of diplomatic relations with the GDR in 1973, state-level interactions with East Germany were framed in the news as being of high national importance. Axen's visit to Finland was followed by that of Foreign Minister Otto Winzer in July 1973, the Head of the State Willi Stoph in October 1974, and Foreign Minister Oskar Fischer in 1976 - all reported by YLE television news. When the longtime head-of-state of Finland, President Urho Kekkonen, visited the GDR in September 1977, the upcoming state visit was reported on for days before it actually took place, and the president's departure and return were both reported on-location at Helsinki Airport.

Notwithstanding the foreign political motives, the primary goal for state-level visits between the GDR and Finland throughout the 1970s seems to have been to create conditions and support for economic collaboration. During his state visit to the GDR, President Kekkonen was accompanied by a trade delegation representing Finnish companies. Kekkonen's visit to the GDR was followed by news reports on the third concrete element factory to be built in the GDR by the Finnish company Partek and a new chipboard factory built by Finnish Metex. The economic prospects of the GDR were also analysed in the weekly YLE current affairs programme Ajankohtainen Kakkonen (8 September 1977) while a report on the GDR car industry in another YLE current affairs programme followed the same line of reporting (A-Studio, 9 September 1977). Although the FRG was economically a far more important trade partner for Finland than the GDR, the news programming showcased the prosperity of the GDR and created a sense of faith in their future as a socialist economy.

Sense of faith was also created through long-term and continual personal communication between state officials. President Kekkonen's visit to the GDR in 1977 was followed by the Finnish Foreign Minister Paavo Väyrynen's visit in 1981, Honecker's visit to Finland in October 1984, Prime Minister Kalevi Sorsa's visit to the GDR in September 1985, Foreign Minister Oskar Fischer's visit to Finland in August 1986, and President Mauno Koivisto's visit to the GDR in September 1987. Scheduling the visits at the same time every year alludes to annual ratifications of bilateral contracts such as the KEVSOS free trade contract. In addition to commercial agreements, the visits concerned a bilateral agreement on advancing tourism between the GDR and Finland. (The Prime Minister of Finland, Kalevi Sorsa, signed one such agreement during his state visit to the GDR in September 1985, reported by YLE News on 9 November 1985.) News and current issues on the stable diplomatic and trade relations between the countries created an atmosphere of trust and predictability, which could be seen as serving the national interests of both Finland and East Germany. 


\section{Honecker and history politics}

Taking the expected economic advantages into consideration, the interest in the GDR economy in 1970s Finnish television news is hardly surprising. More unexpected subjects of news are the diligent reports of annual SED party meetings and various bilateral interactions and negotiations between the two German states. Throughout the 1970s and 1980s, SED leader Erich Honecker's international visits and meetings were reported on YLE television news regularly, despite them having no direct connection to Finland or Finnish foreign politics. In addition to the numerous visits and meetings with the Soviet leaders, YLE News reported on Honecker's meeting with Deng Xiaoping in China in 1986 (23 October 1986) and the following year with Wolfgang Schäuble, then head of the Chancellery under Helmut Kohl's reign (YLE News, 27 March 1987).

Honecker, evidently seen as one of the Cold War's central players, was reported as criticising the American air attack on Libya in his opening speech of the annual SED meeting in Berlin in 1985 (YLE News, 17 April 1985). When Honecker visited Finland in 1984, he was asked to comment on relations between the United States and the Soviet Union, hence positioning the East German leader in a guarantor role in matters concerning European security (YLE News, 18 October 1984). In the mid-1980s, East Germany was indeed the centre point of the European Cold War; the situation in Europe had become more tense because of the Euro-Missile crisis and the wave of refugees striving to escape East Germany through the West German embassy. The first news about GDR citizens seeking asylum in the West found in the YLE Metro database are from November 1984, when it was stated that nearly one hundred GDR refugees seeking asylum at FRG embassies in Prague and Budapest were returned to East Germany (YLE News, 13 November 1984). In December 1984, it was reported that a group of East German refugees were on hunger strike at the FRG embassy in Prague (YLE News, 20 December 1984). These reports drew on footage provided by the West German public service broadcasting company, available to YLE News.

The visibility of the SED and Honecker can be explained by DDR-FS news footage being available for YLE news and current issues through OIRT Intervision news exchange network - all the above examples of the reporting about Honecker's meetings used DDR-FS footage as their source material. When Honecker's historic visit to West Germany was announced, the event was followed up on Finnish television for days. Through YLE current affairs programming, Finnish television viewers were invited to follow Honecker to the streets of his hometown in the Saarland and to the Dachau concentration camp (A-Studio, 7 September 1987). Throughout the visit, the reports were filled with optimistic analyses of the eventual normalisation of relations between the two German states. The increased travel clearances from East to West Germany and the shared concerns and efforts in the fields of environmental protection and disarmament were seen as signs of reconciliation. For Honecker, the most important issue was to ensure that war would never again break out on German soil - as he stated in his speech in Bonn, according to YLE - a reminder of the historical background of the ideological division of Germany (A-Studio, 7 September 1987).

On Finnish television, the historical memory of the division of German states had been kept alive by a number of documentaries on German history and the GDR as a socialist state model. ${ }^{4}$ Through the German history documentaries, Finnish television viewers were reminded of the course of history that led to the present state of affairs: 
the division of Germany into two ideologically opposite states. Furthermore, the documentaries stated that after the catastrophe of World War II, the present situation appeared as an era of peace and prosperity on both sides of the Wall. The documentaries used Intervision network footage, DDR-FS archive footage, and interviews with East German historians, and would not have been possible without East German involvement. Nevertheless, YLE's broadcasting of these documentaries indicates a genuine interest in the subject from the Finnish side. Complying with East German history perception and using DDR-FS footage testifies to the reciprocal nature of the relationship between YLE and DDR-FS and the television diplomacy practised in the level of editorial decision-making and journalistic work.

\section{Representations of everyday life}

Our third category consists of current issues reports, documentaries, and programmes about everyday life in East Germany; this material balanced the ceremonial characteristics of state visit reports. The curious eye of the camera peeked into shops, street corners, and people's private homes to catch glimpses of life behind the Wall. East German young people and their views, opinions, and hopes for the future were, for example, introduced in two separate current issues programmes reported by YLE foreign correspondent Knud Möller (The World of the 25-year-olds: East Germany aired 20 May 1970, and Foreign Affairs Report: The GDR Youth aired 8 October 1972). The youth festival in East Berlin in August 1973 was also broadly covered, including lengthy interviews with a number of Finnish youth politicians participating in the festival. A subject to which YLE also devoted airtime was the role and societal position of women in East Germany. A documentary titled The GDR Women, broadcast on 6 October 1974, emphasised the country's progressive kindergartens and opportunities for women to participate fully in society and professional life.

Everyday life in the GDR was also covered through news inserts and programmes about housing. In July 1975, for example, television news reported on the reconstruction of old Berlin houses in order to remedy the housing shortage in East Berlin (YLE News, 5 July 1975). Housing was also discussed in a two-part documentary co-produced by YLE and DDR-FS: the first part dealt with housing in the GDR under the title Home for 17 Million - Living in the GDR, while the second concentrated on housing in Finland with the title Living in Finland. Both parts where broadcast by YLE (on 5 and 12 February) and DDR-FS (on 12 February and 24 July) in 1978 (Yleisradio-Finnland, Box 07 [1972-1985], DRA Archive, Potsdam). The archived work plans and correspondence show that the documentaries on GDR women and youth, and on housing, were produced in collaboration and necessitated long-term planning, discussions, and preparations. ${ }^{5}$

Similar themes and issues of housing and work, the future prospects of young people, the role of women, and political engagement were discussed in the numerous feature films produced by DDR-FS and the state-owned film studio Deutsche Film-Aktiengesellshaft. These included films such as Eva und Adam (1973: YLE 1, 4 September 1973) about the equality in modern marriage, the two-part drama Die Grosse Reise der Agathe Schweigert [The Great Journey of Agathe Schweigert](1972: YLE, 25-26 September 1973), and the romantic comedy Die Legende von Paul und Paula [The Legend of Paul and Paula] (1973: YLE, 18 March 1977). The GDR as fruitful ground for contemporary 
literature and modern science was introduced in portrait documentaries about East German novelist Christoph Hein (YLE 1, 22 August 1988) and East German cancer researcher Manfred Ardenne (YLE 1, 21 June 1989). Evidence of plans to produce a programme about East German author Krista Wolf can also be found in the DRA archive (Yleisradio-Finnland, Box 09 [1976-1989], Potsdam).

In the late $1980 \mathrm{~s}$ there were, it appears, a number of journalists in the YLE culture department with an appreciative eye for socialist East Germany and its contributions. At the same time, the growing migration from East Germany to West Germany via Hungary and Austria, the refugees camping at the West German embassy, and the protests of the East German citizens were broadly reported in YLE news and current issues programmes. However, it is evident that in Finland, the political, cultural, and media elite believed until the very end that the situation would stabilise and the GDR as a state model would remain. Faith in normalisation and maintaining Cold War status quo was rooted in the editorial decisions, programme planning, and political language, and it is also evident in the variety of East German and Soviet experts offered airtime during the mass demonstrations. In May 1989, for example, YLE interviewed Heinz Hummler from the GDR Central Committee, journalist Karl Eduard von Schnitzler (infamous for his leading role in the blatant propaganda programme Der schwarze Kanal [The Black Channel]), and the chair of the East German legislature Horst Sindermann about the reform process in Eastern Europe (A-Studio, 22 May 1989 \& YLE News, 17 May 1989). In addition to this, the Soviet Chief of the General Staff, Sergey Akhromeyev, commented on the events from a military perspective; to the viewers of YLE News, Akhromeyev assured that the ongoing GDR refugee crisis did not weaken the Warsaw Pact (11 September 1989).

In fact, very few Finnish experts commented on the ongoing events on television. Only two expert interviews could be found in the Metro database: national economist Pekka Sutela (A-Studio, 6 October 1989) and historian Seppo Zetterberg (YLE News, 10 November 1989). As it appears from the Metro search results, the first politician to comment on the eventual fall of the Berlin Wall was Foreign Minister Pertti Paasio, who gave a short statement on YLE News the morning after the opening of the border (on the evening of 9 November).

The overall spirit of status quo can be seen in the continuous flow of DDR-FS films and cultural programmes in television. During the autumn months of 1989, YLE broadcast a cultural programme, Introducing Helsinki GDR Cultural Centre [DDRKulturzentrum esittäytyy], which included an interview with the then-manager HansHorst Bethge (YLE 1, 22 September 1989) and the Intervision music programme G-Note [G-avain] (YLE 1, 4 November 1989). Sandwiched between news on mass demonstrations and thousands of refugees escaping the country, these programmes reflect both the unexpectedness of the magnitude of ongoing changes and how rooted the spirit of status quo was at YLE.

\section{Conclusion}

Earlier research on Finnish media during the Cold War has focused strictly on Soviet relations. By analysing textual metadata from the YLE Metro database, we have shown in this article evidence of long-term interest in East Germany in Finnish television. 
Moreover, to draw attention to the affordances of broadcast television as a medium, arena, and instrument in European Cold War public diplomacy, we have suggested the notion of television diplomacy. In the Finnish Cold War political history context, this is an attempt to redirect the focus from debates about Finlandisation to documented company level communication, actual agreements, and editorial decision making.

Finnish-East German television diplomacy manifests itself in the repetitious handshakes of state representatives at the airport and the recurring images of Erich Honecker (provided through DDR-FS news footage). Moreover, television diplomacy is seen in the co-produced documentaries about the history and everyday life in GDR, in the imported feature films of the state-owned film studio Deutsche Film-Aktiengesellshaft, and in the culture programmes produced in collaboration with DDR-FS. From the GDR perspective, the long-term interest in increasing visibility of the GDR in Finnish television was probably driven by the wish to promote the GDR as a socialist state model. YLE's interest in the collaboration is explained by the company's programme policy principles of balancing and complying to the foreign policy of Finland, but also by a genuine interest in East Germany and its economy, history, culture, and everyday life. The analysed metadata indicate that this interest existed at different YLE departments, from news and current issues to those dealing with film import and culture programming.

In fact, the Metro database search results show the variety of GDR-related programmes that were broadcast on Finnish television. Notwithstanding the possible shortages of database entries, the search results give an idea about the volume, frequency, sources, and interest in subjects related to the GDR. Moreover, in contrast to other means of gathering information on types of programming, the database result shows the GDR both as subject of news journalism and subject of culture programming. Until now, these have been discussed within their separate research frameworks and publishing platforms in the fields of political history, media and communication research, and popular television history. By shedding light on the variety of GDR-related programming, the YLE metro database search results provide a nuanced understanding of the role of public service television companies as part of European Cold War public diplomacy. Similar analyses of other Nordic public service television companies and their collaboration with East German television should be valued, since we would then be able to discuss GDR television diplomacy in an entire - and from the GDR perspective, important - region.

\section{Notes}

1. This research was carried out with support from The Crafoord Foundation.

2. A selection of actual programmes and clips is available at the online database YLE Elävä Arkisto. Programmes can also be accessed from the RITVA radio and television database, available at the National Audiovisual Institute in Helsinki and the university libraries in Helsinki, Tampere, and Turku. The archiving criteria for the RITVA database follow the YLE archive criteria. The oldest televised materials are digitised and made available systematically, while the newer ones are archived as thematic selections and collections.

3. The broadcasting collaboration with the OIRT countries within the Intervision network was limited because of various technical incompatibilities. Hence, the programme exchange and co-productions were mostly executed through bilateral exchange contracts. The first bilateral contract between DDR-FS and YLE was drawn up on 10 September 1966 (Box 06 Yleisradio-Finnland [1967-1976], DRA archive, Potsdam).

4. These included the following documentary programmes:

- Ulkomaanraportti: Berliini [Foreign news report: Berlin] (1971)

- Mitä muurin jälkeen? [What after the wall?] (1971) 
-Vanha maa - nuori valtio: DDR tänään [Old country - young state: The GDR today] (1979)

- DDR - Saksan Demokraattinen Tasava [The GDR - The German Democratic Republic] (1981)

- Jaltan henki [The Spirit of Yalta] \& Rautaesirippu: Jalta 2 [Iron Curtain: Yalta 2] (1983)

- Berliini: Muurikaupunki [Berlin: The wall city] (1985)

-Berliini 750 vuotta - Mutkallinen syntymäpäivä [The complicated history of 750-year-old Berlin] (1987).

5. See, for example, Memo on "Women in the GDR" by YLE correspondent Knud Möller, DDR-FS production for Finnish television (dated 15 May 1974, Yleisradio-Finnland, Box 06 [1967-1976], DRA archive, Potsdam). In the agreements, memos, and correspondence concerning co-productions, there are several direct references to the GDR as a modern welfare state. The documents also show that the documentaries were initiated by DDR-FS.

\section{References}

Abraham, N. (2007). Die politische Auslandsarbeit der DDR in Schweden: Zur public diplomacy der DDR gegenüber Schweden nach der diplomatische Anerkennung 1972-1989 [The GDR's international political work in Sweden: On the public diplomacy of the GDR vis-à-vis Sweden after diplomatic recognition in 1972-1989]. Berlin: Lit.

Almgren. (2009). Inte Bara Stasi. Relationer Sverige-DDR 1949-1990 [Not just Stasi. The Sweden-GDR relations 1949-1990]. Stockholm: Carlssons.

Autio-Sarasmo, S., \& Miklóssy, K. (Eds.) (2011). Reassessing Cold War Europe. London: Routledge.

Badenoch, A., Fickers, A., \& Henrich-Franke, C. (Eds.) (2013). Airy curtains in the European ether: Broadcasting and the Cold War. Baden-Baden: Nomos.

Beutelschmidt, T., \& Oehmig, R. (2014). Connected enemies? Programming transfer between East and West during the Cold War and the example of East German television. VIEW Journal of European Television History and Culture, 3(5), 60-67. http://doi.org/10.18146/2213-0969.2014.jethc056

Cohen, Y. (1986). Media diplomacy: The Foreign Office in the mass communications age. London: Frank Cass. Couldry, N., Hepp, A., \& Krotz, F. (Eds.) (2009). Media events in a global age. London: Routledge.

Dayan, D., \& Katz, E. (1992). Media events: The live broadcasting of history. Cambridge, Massachusetts: Harvard University Press.

Gilboa, E. (2001) Diplomacy in the media age: Three models of uses and effects. Diplomacy and Statecraft, 12(2), 1-28. https://doi.org/10.1080/09592290108406201

Henrich-Franke, C., \& Immel, R. (2013). Making holes in the Iron Curtain?: The television programme exchange across the Iron Curtain in the 1960s and 1970s. In A. Badenoch, A. Fickers, \& C. Henrich-Franke (Eds.), Airy curtains in the European ether: Broadcasting and the Cold War (pp. 175-214). Baden-Baden: Nomos.

Hentilä, S. (2004). Harppisaksan haarukassa. DDR:n polittinen vaikutus Suomessa [GDR's political influence in Finland]. Helsinki: SKS.

Hentilä, S. (2006). Maintaining neutrality between the two German states: Finland and divided Germany until 1973. Contemporary European History, 15(4), 473-493. https://doi.org/10.1017/S096077730600350X

Imre, A., Havens, T., \& Lustyik, K. (Eds.) (2013). Popular Television in Eastern Europe during and since socialism. New York: Routledge.

Linderoth, A. (2002). Kampen för erkännande: DDR's utrikespolitik gentemot Sverige 1949-1972. [The struggle for recognition: GDR foreign policy towards Sweden 1949-1972] Lund: Lund University.

Lounasmeri, L. (2013). Through rose or blue and white glasses?: Decades of news about the Soviet Union in the Finnish Press. Nordicom Review, 34(1), 105-123. https://doi.org/10.2478/nor-2013-0046

Lundgren, L. (2015). Transnational television in Europe: Cold War competition and cooperation. In S. Mikkonen, \& P. Koivunen (Eds.), Beyond the divide: Entangled histories of Cold War Europe (pp. 237-256). New York: Berghahn.

Lundgren, L., \& Evans, C. (2017). Producing global media memories: Media events and the power dynamics of transnational television history. European Journal of Cultural Studies, 20(3), 252-270. https://doi. org/10.1177/1367549416682240

Malek, A. (1997). News media and foreign relations: A multifaceted perspective. Norwood: Ablex.

Melissen, J. (Ed.) (2005). The new public diplomacy: Soft power in international relations. Basingstoke: Palgrave Macmillan.

Mihelj, S. (2013). Television entertainment in socialist Eastern Europe: Between Cold War politics and global developments. In T. Havens, A. Imre, \& K. Lustyik (Eds.), Popular television in Eastern Europe during and since socialism (pp. 13-29). New York: Routledge.

Mikkonen, S., \& Koivunen, P. (Eds.) (2015). Beyond the divide: Entangled histories of Cold War Europe. New York: Berghahn Books. 
Mikkonen, S., Scott-Smith, G. \& Parkkinen, J. (Eds.) (2019). Entangled East and West: Cultural diplomacy and artistic interaction during the Cold War. Berlin: De Gruyter.

Mikkonen, S., \& Suutari, P. (Eds.) (2016). Music, art, and diplomacy: East-West cultural interactions and the Cold War. Burlington: Ashgate.

Minholz, M., \& Stirnberg, U. (2012). Der Allgemeine Deutche Nachrichterdienst (ADN): gute nachrichten für die SED [The GDR News Agency (ADN): Good news for the SED]. Berlin: De Gruyter.

Mustata, D. (2012). Television in the age of (post)communism: The case of Romania. Journal of Popular Film and Television, 40(3), 131-140. https://doi.org/10.1080/01956051.2012.697794

Pajala, M. (2014). East and West on the Finnish screen: Early transnational television in Finland. View: Journal of European Television History and Culture, 3(5), 88-99. Retrieved January 25, 2020, from http://ojs. viewjournal.eu/index.php/view/article/view/JETHC059

Pajala, M. (2018a). A forgotten spirit of commercial television?: Co-productions between Finnish commercial television company Mainos-TV and socialist television. Historical Journal of Film, Radio and Television, 39(2), 366-383. https://doi.org/10.1080/01439685.2018.1527063

Pajala, M. (2018b) "Images from beyond the Eastern border": Socialist television in Finland, 1963 to 1988. Television \& New Media, 19(5), 448-466. https://doi.org/10.1177/1527476417721749

Pamment, J. (2016). British public diplomacy and soft power: Diplomatic influence and digital revolution. London: Palgrave Macmillan.

Pernaa, V. (2009). Uutisista hyvää iltaa [Good evening from the news]. Helsinki: Karttakeskus.

Richmond, Y. (2003). Cultural exchange and the Cold War: Raising the iron curtain. University Park: Pennsylvania State University Press.

Richmond, Y. (2008). Practicing public diplomacy: A Cold War odyssey. New York: Berghahn Books.

Rusi, A. (2007). Vasemmalta ohi. Kamppailu Suomen ulkopoliittisesta johtajuudesta rautaesiripun varjossa 1945-1990 [The Struggle over foreign political leadership of Finland in the shadows of the Iron Curtain 1945-1990]. Helsinki: Gummerus.

Rusi, A. (2012). Tiitisen lista: Stasin vakoilu Suomessa 1960-1989 [Tiitinen's List: Stasi in Finland 19601989]. Helsinki: Gummerus.

Salminen, E. (1999). The silenced media: The propaganda war between Russia and the West in Northern Europe. London: Macmillan.

Salokangas, R. (1996). Aikansa oloinen: Yleisradion historia 1926-1996 [History of Finnish Broadcasting Company 1926-1996]. Helsinki: WSOY.

Salokangas, R. (2015). In the Shadow of the Bear. In H. Bastiansen \& R. Werenskjold (Eds.), The Nordic Media and the Cold War (pp. 67-100). Gothenburg: Nordicom.

Seppinen, J. (2011). Suomettumisen syövereissä [In the thicket of Finlandisation ]. Helsinki: WSOY.

Strandgaard Jensen, H. (2016). Doing media history in a digital age: Change and continuity in historiographical practices. Media Culture and Society, 38(1), 119-128. https://doi.org/10.1177/0163443715607846

Uskali, T. (2003). Älä kirjoita itseäsi ulos: Suomalaisen Moskovan-kirjeenvaihtajuuden alkutaival 1957-1975 [Don't write yourself out: The beginning of the Finnish Moscow correspondence 1957-1975]. Jyväskylä: University of Jyväskylä.

Vihavainen, T. (1991). Kansakunta rähmällään: Suomettumisen lyhyt historia [The nation is shaking: A brief history of Finlandisation]. Helsinki: Otava.

Vowinckel, A., Payk M., \& Lindeberger T. (Eds.) (2012). Cold War cultures: Perspectives on Eastern and Western societies. Oxford: Berghahn Books.

Åkerlund, A. (2011). Kulturtransfer och kulturpolitik: Sverige och Tyskland under det tjugonde århundradet [Cultural transfer and cultural policy: Sweden and Germany during the twentieth century]. Uppsala: Historiska Institutionen.

Copyright: (C) 2020 The Author(s) and Nordicom. This is an Open Access article distributed under the terms of the Creative Commons Attribution 4.0 International License (CC BY-NC-ND 4.0). 